\title{
The susceptibility of FSHB -211G $>$ T and FSHR G-29A, 919A > G, 2039A > G polymorphisms to men infertility: an association study and meta-analysis
}

Qiuyue $\mathrm{Wu}^{\dagger}$, Jing Zhang ${ }^{\dagger}$, Peiran Zhu, Weijun Jiang, Shuaimei Liu, Mengxia Ni, Mingchao Zhang, Weiwei Li, Qing Zhou, Yingxia Cui and Xinyi Xia ${ }^{*}$ (D)

\begin{abstract}
Background: Male infertility is a complex disorder caused by genetic, developmental, endocrine, or environmental factors as well as unknown etiology. Polymorphisms in the follicle stimulating hormone beta subunit (FSHB) (rs10835638, c.-211G > T) and follicle stimulating hormone receptor (FSHR) (rs1394205, c.-29G > A; rs6165, c. 919A > G; rs6166, c.2039 A > G) genes might disturb normal spermatogenesis and affect male reproductive ability.

Methods: To further ascertain the aforementioned effects, we conducted a case-control study of 255 infertile men and 340 fertile controls from South China using the Mass ARRAY method, which was analyzed by the t-tests and logistic regression analysis using SPSS for Windows 14.0. In addition, a meta-analysis was performed by combining our results with previous reports using STATA 12.0.

Results: In the FSHB or FSHR gene single nucleotide polymorphism (SNP) evaluation, no statistically-significant difference was found in the frequency of allelic variants or in genotype distribution between cases and controls. However, a significant association for the comparison of GAA (P: 0.022, OR: 0.63, 95\%Cl: 0.43-0.94) was seen between the oligozoospermia and controls in haplotype analysis of rs1394205/rs6165/rs6166. In the meta-analysis, rs6165G allele and rs6166 GG genotype were associated with increased risk of the male infertility.

Conclusions: This study suggested that FSHR GAA haplotype would exert protective effects against male sterility, which indicated that the combination of three SNP genotypes of FSHR was predicted to have a much stronger impact than either one alone. Then in the meta-analysis, a significant association was seen between FSHR rs6165, rs6166 polymorphisms and male infertility. In terms of male infertility with multifactorial etiology, further studies with larger sample sizes and different ethnic backgrounds or other risk factors are warranted to clarify the potential role of FSHB and FSHR polymorphisms in the pathogenesis of male infertility.
\end{abstract}

Keywords: Male infertility, FSHB gene, FSHR gene, Polymorphisms, Case-control study, Meta-analysis

\footnotetext{
* Correspondence: xiaxynju@163.com

†'Equal contributors

Institute of Laboratory Medicine, Jinling Hospital, Nanjing University School

of Medicine, Nanjing 210002, People's Republic of China
} 


\section{Background}

Worldwide, approximately $15 \%$ of couples cannot have a child, and in half of the cases the reason is the result of male infertility [1], which is a complex disorder caused by genetic, developmental, endocrine, or environmental factors or still unknown etiology [2]. It has been demonstrated that approximately $30 \%$ of infertility cases could be attributed to genetic defects, such as Klinefelter syndrome (KS), disorders of sexual development (DSD), or congenital absence of the vas deferens. Therefore, it is necessary to prevent and treat male infertility from the genetic viewpoint [3].

Nowadays, increasing numbers of researchers have focused their attention on the relationship between genetic polymorphisms and male infertility, including methylenetetrahydrofolate reductase $(M T H F R)[4,5]$, deleted in azoospermia like gene $(D A Z L)[6,7]$, androgen receptor gene (AR) [8], glutathione S-transferase genes (GSTM1, GSTT1, GSTP1) [9-11] and follicle stimulating hormone receptor gene (FSHR, OMIM:136,435) [12-14], or FSH beta subunit (FSHB,OMIM:136,530) [15].

FSH acts as a spermatogonial survival factor in the adult testis and is also a necessary signal for Sertoli cell proliferation, a process that occurs during fetal, neonatal, and prepubertal life [16]. FSH is a double-stranded glycoprotein consisting of two chains, including 92 amino acids forming the $\alpha$ chain and 111 amino acids comprising the $\beta$ chain, which are coupled by a noncovalent bond [17]. Most clinical studies reported so far only focused on the single nucleotide polymorphism (SNP) rs10835638 (c.-211G > T), which is located in an element of the FSHB promoter influencing gene transcription by affecting the binding of the LHX3 homeodomain transcription factor $[15,18,19]$. In order to exert its stimulatory effect, FSH binds to its receptor, the FSHR expressed on the membrane of granulosa cells (GCs) in the ovary and Sertoli cells in the testis to bring about folliculogenesis [20] and spermatogenesis [21], respectively. The FSHR gene is located on chromosome 2p21 and consists of 9 introns and 10 exons [22]. Given the significant role of FSH in fertility, genetic abnormalities of the FSHR could cause infertility. FSHR SNP rs6166 exchanges asparagine (Asn) for serine (Ser) in the intracellular domain of the receptor, introducing a potential phosphorylationsite; while rs6165 replaces threonine (Thr) with alanine (Ala), resulting in a change from a polar $(\mathrm{T})$ to a nonpolar, hydrophobic (A) amino acid and removing a potential O-linked glycosylation site [22]. A previous studies in human granulosa-lutein cells (hGLC) has revealed that the two FSHR polymorphisms, blunted ERK1/2 (extracellular regulated protein kinases $1 / 2$ ) activation, which indicated that Ala307-Ser680 FSHR was indeed less "active" in vitro, providing a molecular explanation for the clinical data [23]. Clinical studies suggested that those men with both mutated FSHR variants may have significantly higher basal serum FSH levels. SNP (rs1394205) exchanges a nucleotide in the promoter region of the FSHR gene (c.-29G > A), resulting in a significant $56 \%$ decrease in the transcriptional promoter activity of A allele [18]. In summary, SNPs involved either in signal transduction (FSHR exon 10 ) or in transcriptional activity (FSHR and FSHB promoter) in vitro could result in an overall change of FSH action.

Among these candidates, the linked SNPs at positions 307 and 680 in exon 10 of the FSHR gene have been extensively investigated as the potential cause of male infertility in various ethnic populations [14, 22, 24, 25], and the results largely failed to demonstrate significant associations. Polymorphism rs1394205 is located in the $5^{\prime}$ - untranslated region (5'-UTR) of FSHR (c.-29G/A), which has been reported to affect the serum level of FSH [22]. For the FSHB, rs 10835638 is a $-211 \mathrm{G}>\mathrm{T}$ polymorphism located in the element of the FSHB promoter, which has been reported to be associated with lower testicular volume, lower sperm count, lower testosterone, and higher luteinizing hormone $(\mathrm{LH})$ serum levels $[18,22]$. However, the associations between these SNPs in the FSHR gene and FSHB and male infertility remain uncertain.

To further verify the effects of the polymorphisms (FSHB rs10835638, FSHR rs6165, rs6166, rs1394205) on the risk of male infertility and to quantify potential heterogeneity between various studies, we conducted a case-control study of 255 infertile men and 340 healthy controls from South China, as well as performing a meta-analysis of the results of previous reports and this study.

\section{Methods \\ Study population}

Only men of Han-Chinese ethnicity were recruited between April 2013 and July 2015 among the participants in the Institute of Laboratory Medicine, Jinling Hospital, Nanjing University School of Medicine. This study population was consisted of 340 fertile men as healthy control, who had at least 1 child in the last year by direct survey and lacked any history of requiring assisted reproduction technology, and 255 infertile men, including 166 with azoospermia or severe oligozoospermia (sperm concentration $<5 \times 106 / \mathrm{ml}$ ), and 89 with oligozoospermia (sperm concentration $5-15 \times 106 / \mathrm{ml}$ ), with at least 1 year of infertility. Individuals with known causes of infertility including genetic factors (chromosome anomalies), AZF microdeletions, clinical factors (varicocele, crytorchidism), obstructive azoospermia and infections were excluded from this study. All controls and cases were ethnic Han-Chinese. 


\section{Evaluations}

All the enrolled patients were examined at least two semen analyses according to the World Health Organization guidelines (WHO, 2010). In brief, after ejaculation, the semen was incubated at $37{ }^{\circ} \mathrm{C}$ for $30-$ $40 \mathrm{~min}$ for liquefaction. Semen volume was estimated by weighing the collection tube with the semen sample and subsequently subtracting the predetermined weight of the empty tube assuming $1 \mathrm{~g}=1 \mathrm{~mL}$. For assessment of the sperm concentration, the samples were diluted in a solution of $0.6 \mathrm{~mol} / \mathrm{L} \mathrm{NaHCO}_{3}$ and $0.4 \%(\mathrm{v} / \mathrm{v})$ formaldehyde in distilled water. The sperm concentration was assessed using the improved Neubauer haemocytometers.

In addition, the participants underwent medical and andrological examination including medical history, hormonal analysis for the measurement of serum $\mathrm{LH}, \mathrm{FSH}$, total testosterone $(\mathrm{T})$, Estradiol $\left(\mathrm{E}_{2}\right)$, Prolactin, karyotype, and $\mathrm{Y}$ chromosome microdeletion screening. Karyotype and Y chromosome microdeletion were determined by G-banding in lymphocytes and multiplex polymerase chain reaction (PCR) using primers (sY84, sY86, sY127, sY134, sY254, sY255, SRY, ZFX/ZFY) specific for the diagnosis of microdeletion of the AZFa, AZFb, and AZFc regions, respectively. Then serum hormone levels were detected by chemiluminescent microparticle immunoassay on an Abott-ARCHITECT Immunoanalyser (Abbott Laboratories Abbott Park, IL, USA). The intraand interassay coefficients of variation $(\mathrm{CV})$ for measurement of both FSH and LH were 3 and $4.5 \%$, for total testosterone $<8 \%$ and $<5 \%$, for estradiol $7.5 \%$ and $13 \%$, respectively.

\section{Genomic DNA extraction and genotyping}

Genomic DNA was extracted from the peripheral blood of the 255 infertile men and 340 fertile men using a blood DNA extraction kit (TIANGEN, Beijing, China). The DNA purity was measured by spectrometry (DU530UV/VIS spectrophotometer, Beckman Instruments, Fullerton, CA, USA). Genotyping was performed using the Mass ARRAY platform [26, 27]. In brief, SNPs were detected by Sequenom Mass ARRAY RS1000 according to the standard protocol. Multiplexed SNP Mass EXTENDED assay was designed by Sequenom Mass ARRAY Assay Design 3.0 Software version. The primers were: for codon 307 polymorphism, forward primers $5^{\prime}$ TTCTACCCTGCACAAAGACAG-3', reverse primer 5' - AATCCTCTGCTGTAGCTGGAC-3'; for codon 680 polymorphism, forward primers $5^{\prime}$-CACTGTCCACAA CACCCATCC-3', reverse primer $5^{\prime}$ - ACCCTTCAAA GGCAAGACTGA-3'; for nucleotide position -29 polymorphism, forward primer 5' -ACGTTGGATGCAGGG CCATAATTATGCATC-3', reverse primer $5^{\prime}$-ACGTT GGATGTGTGGAGCTTCTGAGATCTG-3'; for nucleotide position -211 polymorphism, forward primer
5' -ACGTTGGATGCTAAAGTAGTCTAAACGCAG-3', reverse primer $5^{\prime}$-ACGTTGGATGAGTGGGTGTGC TACTGTATC-3'. Finally, data management and analyses was performed by Sequenom Mass ARRAY Analyzer 4.0 system. Then the effectiveness of this method was verified by direct sequencing analysis (ABI PRISM3730XL DNA Sequencer; Applied Biosystems) of the first 100 DNA samples.

\section{Meta-analysis \\ Study selection}

To identify the related articles, a comprehensive systematic searching was performed in the PubMed, Web of Science and the Chinese National Knowledge Infrastructure (CNKI) database, using the search words "FSHR rs6165”, “FSHR rs6166”, "FSHR rs1394205”, "polymorphism" and "male infertility". Included studies had to meet the following criteria: (1) evaluation of the FSHR rs1394205, rs6165, rs6166 and male infertility; (2) involving in human beings; (3) a case-control study; (4) with detailed genotype frequency of cases and controls or obtained the article text.

\section{Data extraction and verification}

Two authors (Qiuyue Wu and Jing Zhang) extracted the data independently that met the inclusion criteria and reached the consensus for any controversy. The main characteristics of enrolled studies were listed, including: (I) First author's name, (II) Year of publication, (III) Race, (IV) Control sources, (V) Genotyping methods, (VI) Polymorphism sites, (VII) Control/Case counts,(VII) Genotype counts (control/case), (IX) Hard-Weinberg equilibrium (HWE) in the controls and (X) Clinical diagnose of cases.

\section{Statistical analysis and meta-analysis Analysis of genetic data}

T-test was used to measure the differences in the distributions of clinical characteristics, including age, hormone and sperm parameters between groups and cases. The difference of FSHR rs1394205, rs6165 and rs6166 polymorphism and FSHB rs10835638 polymorphism between the infertile and fertile groups was calculated using a logistic regression model, SNPs coded as three categories: wild-type homozygote (WW, reference), the heterozygous (WR) and rare allele homozygote (RR), which yielded a $p$ value and odds ratio (OR) with the corresponding 95\% confidence interval (CI), using SPSS for Windows 14.0 (SPSS, Inc., Chicago, Illinois). And $P<0.05$ was considered statistically significant. The linkage disequilibria and haplotypes were analyzed with SHEsis software (http://analysis.bio-x.cn/SHEsisMain.htm). Because only the data of Age was collected completely, genetic association tests have been adjusted for Age effects. 


\section{Statistics for meta-analysis}

This study and other related case-control studies were combined for the meta-analysis, which was performed using STATA 12.0 (STATA Corporation LP, College Station, TX, USA). Odds ratio (OR) and 95\% confidence interval $(\mathrm{CI})$ were calculated to estimate the associations of FSHR rs6165、 rs6166、rs1394205 polymorphisms with male infertility susceptibility based on three genetic models, including co-dominant model [the rare allele homozygote (RR) vs. wild-type homozygote (WW), the heterozygous (WR) vs. WW], dominant model (RR + WR vs. WW), recessive model (RR vs. WW + WR). In addition, stratified analyses were performed by HWE $(>0.05$ and $<0.05)$, race (Caucasian, Asian and Brazilian population) and case counts $(>200$ and $<200)$. HWE $<0.05$ indicates unbalanced distribution in the frequency of the population. So studies with SNPs with HWE $<0.05$ were removed from metaanalysis. Heterogeneity across the studies was evaluated by $\mathrm{t}$-test test based on $\mathrm{Q}$ test and was considered significant if $P$-value for heterogeneity $\left(P_{\mathrm{h}}\right)$ was $<0.05$. A fixed-effect model with no heterogeneity $\left(P_{\mathrm{h}}>0.05\right.$ or $\left.\mathrm{I}_{2}<50 \%\right)$ using the Mantel-Haenszel method and a random effects model with a high heterogeneity $\left(P_{\mathrm{h}}<0.05\right.$ or $\left.\mathrm{I}_{2}>50 \%\right)$ using the DerSimonian and Laird method were used to pool the results. Moreover, a sensitivity analysis, by which a single study in the meta-analysis was deleted each time to determine the influence of the individual data set to the overall pooled OR, was performed to assess the stability of the results. To test the publication bias, Begg's Funnel plots and Egger's linear regression test were applied. HWE in the controls of each study was calculated using a web-based program (http://ihg.gsf.de/cgi-bin/hw/hwa1.pl).

\section{Results}

\section{Clinical characteristics of the study population}

A total of 255 infertile men and 340 infertile men were collected in this case-control study. The clinical charactereristics of the participants were presented in Table 1. The observed frequencies of all tested genotypes in controls were in agreement with the HWE ( $P$ : 0.538 for $F S H B$ rs10835638, P: 0.975 for FSHR rs1394205, $P$ : 0.884 for rs6165, $P: 0.391$ for rs6166, respectively). The serum FSH and $\mathrm{LH}$ concentrations in fertile men were $4.72 \pm 2.51 \mathrm{IU} / \mathrm{L}$ and $3.37 \pm 1.46 \mathrm{IU} / \mathrm{L}$, whereas the $\mathrm{FSH}$ and $\mathrm{LH}$ values in infertile patients were $15.73 \pm 16.15 \mathrm{IU} / \mathrm{L}$ and $6.46 \pm 4.98 \mathrm{IU} / \mathrm{L}$, respectively. The FSH and LH levels in the infertile patients were significantly higher than that in the fertile men $(P<0.05)$. And fertile men had higher sperm concentration and sperm motility compared with the infertile men. No statistical difference was observed in the other indicators.

\section{Case-control study of $F S H$ and FSHR gene polymorphisms} Logistic regression analysis revealed that, when the FSHR SNPs at nucleotide -211, -29, codon 307 and codon 680 was separately analyzed, no statistically significant difference was found in the frequency of allelic variants or in genotype distribution between cases and controls, as showed in Table 2.

Haplotype analysis demonstrated that there was a strong linkage disequilibrium (LD) between SNPs $307 / 680\left(\mathrm{D}^{\prime}=0.983, \mathrm{r} 2=0.852\right)$, weak $\mathrm{LD}$ between SNPs $-29 / 307$ ( $D^{\prime}=0.138, \mathrm{r} 2=0.01$ ), and SNPs $-29 / 680$ (D' $=0.195, \mathrm{r} 2=0.018$ ) locuses. A significant association for the comparison of GAA ( $P$ : 0.022, OR: $0.63,95 \% \mathrm{CI}: 0.43-0.94)$ was seen between the oligozoospermia and controls in haplotype analysis of rs1394205/rs6165/rs6166 (Table 3). Furthermore, we evaluated the effects of FSHB-FSHR interactions on the risk of infertility, no significant association was observed in the case and control group.

Table 1 General characteristics of the study group

\begin{tabular}{|c|c|c|c|c|c|c|c|c|}
\hline \multirow[t]{2}{*}{ Clinical parameters } & \multicolumn{2}{|c|}{$\begin{array}{l}\text { Fertile controls } \\
(n=340)\end{array}$} & \multicolumn{2}{|c|}{$\begin{array}{l}\text { Infertile cases } \\
(n=255)\end{array}$} & \multicolumn{2}{|c|}{$\begin{array}{l}\text { Azoospermic or severe } \\
\text { oligozoospermia }(n=166)\end{array}$} & \multicolumn{2}{|c|}{$\begin{array}{l}\text { Oligospermia } \\
(n=89)\end{array}$} \\
\hline & number & Mean \pm SD & number & Mean \pm SD & number & Mean \pm SD & number & Mean \pm SD \\
\hline Age (years) & 340 & $28.37 \pm 4.23$ & 255 & $28.49 \pm 4.51$ & 166 & $28.45 \pm 4.34$ & 89 & $28.56 \pm 4.83$ \\
\hline $\mathrm{T}(9.4-37 \mathrm{nmol} / \mathrm{L})$ & 32 & $12.43 \pm 4.83$ & 71 & $12.34 \pm 4.74$ & 52 & $13.18 \pm 4.60$ & 19 & $13.78 \pm 5.20$ \\
\hline FSH (1-5.5 IU/L) & 32 & $4.72 \pm 2.51$ & 70 & $15.73 \pm 16.15$ & 52 & $19.28 \pm 17.32$ & 18 & $5.46 \pm 2.80$ \\
\hline LH (1-6.3 IU/L) & 32 & $3.37 \pm 1.46$ & 70 & $6.46 \pm 4.98$ & 52 & $7.42 \pm 5.41$ & 18 & $3.69 \pm 1.49$ \\
\hline $\mathrm{E}_{2}(58.6-194.2 \mathrm{pmol} / \mathrm{L})$ & 24 & $103.87 \pm 77.35$ & 42 & $112.00 \pm 68.07$ & 29 & $107.10 \pm 71.75$ & 13 & $122.92 \pm 60.25$ \\
\hline $\mathrm{pH}(7.2-7.4)$ & 177 & $7.38 \pm 0.06$ & 89 & $7.37 \pm 0.07$ & 40 & $7.38 \pm 0.53$ & 49 & $7.36 \pm 0.78$ \\
\hline Semen volume (1.5-6 ml) & 177 & $3.51 \pm 1.39$ & 89 & $3.78 \pm 1.77$ & 40 & $3.52 \pm 1.27$ & 49 & $3.98 \pm 2.09$ \\
\hline Sperm concentration $\left(\geq 15 \times 10^{6} / \mathrm{ml}\right)$ & 340 & $72.77 \pm 45.21$ & 255 & $3.15 \pm 4.52$ & 166 & $0.27 \pm 0.88$ & 89 & $8.53 \pm 3.55$ \\
\hline Sperm motility ( $P R \geq 32 \%)$ & 340 & $42.02 \pm 9.04$ & 255 & $11.76 \pm 17.76$ & 166 & $1.32 \pm 4.92$ & 89 & $31.24 \pm 16.6$ \\
\hline
\end{tabular}

SD standard deviation. Bold numbers was considered to be statistically significant compared with the controls 
Table 2 Allele and genotype frequencies of the FSHR rs6165, rs6166 and rs1394205 genotypes and FSHB rs10835638 genotypes in the infertile and fertile groups

\begin{tabular}{|c|c|c|c|c|c|c|c|c|c|c|}
\hline \multirow[t]{2}{*}{ Genotype } & \multirow{2}{*}{$\begin{array}{l}\text { Control } \\
(n=340) \\
\text { frequency }\end{array}$} & \multicolumn{3}{|c|}{ Case $(n=255)$} & \multicolumn{3}{|c|}{ Sperm concentration $\left(<5 \times 10^{6} / \mathrm{ml}\right)(n=166)$} & \multicolumn{3}{|c|}{ Sperm concentration $\left(5-15 \times 10^{6} / \mathrm{ml}\right)(n=89)$} \\
\hline & & frequency & $P$ & $\mathrm{OR}(95 \% \mathrm{Cl})$ & frequency & P & $\mathrm{OR}(95 \% \mathrm{Cl})$ & frequency & P & $\mathrm{OR}(95 \% \mathrm{Cl})$ \\
\hline \multicolumn{11}{|c|}{ FSHR rs6165Thr307Ala } \\
\hline AA & 0.479 & 0.416 & 0.292 & ref & 0.422 & 0.452 & ref & 0.404 & 0.448 & ref \\
\hline$A G$ & 0.424 & 0.471 & 0.154 & $1.28(0.91-1.81)$ & 0.464 & 0.269 & $1.25(0.84-1.85)$ & 0.483 & 0.232 & $1.35(0.82-2.22)$ \\
\hline GG & 0.097 & 0.113 & 0.285 & $1.35(0.77-2.36)$ & 0.114 & 0.355 & $1.35(0.72-2.53)$ & 0.113 & 0.429 & $1.38(0.62-3.05)$ \\
\hline \multicolumn{11}{|c|}{ FSHR rs6166 Asn680Ser } \\
\hline AA & 0.497 & 0.475 & 0.466 & ref & 0.476 & 0.418 & ref & 0.472 & 0.836 & ref \\
\hline$A G$ & 0.429 & 0.424 & 0.842 & $1.04(0.74-1.46)$ & 0.416 & 0.946 & $1.01(0.68-1.50)$ & 0.438 & 0.770 & $1.08(0.66-1.75)$ \\
\hline GG & 0.074 & 0.101 & 0.219 & $1.45(0.80-2.64)$ & 0.108 & 0.199 & $1.54(0.80-3.00)$ & 0.100 & 0.561 & $1.29(0.54-3.07)$ \\
\hline \multicolumn{11}{|c|}{ FSHR rs1394205-29G > A } \\
\hline GG & 0.229 & 0.208 & 0.704 & ref & 0.241 & 0.328 & ref & 0.146 & 0.136 & ref \\
\hline GA & 0.500 & 0.494 & 0.675 & $1.09(0.72-1.66)$ & 0.434 & 0.427 & $0.83(0.52-1.32)$ & 0.607 & 0.055 & $1.91(0.99-3.71)$ \\
\hline AA & 0.271 & 0.298 & 0.408 & $1.22(0.76-1.93)$ & 0.325 & 0.603 & $1.14(0.69-1.90)$ & 0.247 & 0.348 & $1.43(0.68-3.04)$ \\
\hline \multicolumn{11}{|c|}{ FSHB rs10835638 -211G > T } \\
\hline GG & 0.935 & 0.929 & 0.993 & ref & 0.928 & 0.996 & ref & 0.933 & - & ref \\
\hline GT & 0.065 & 0.067 & 0.908 & $1.04(0.54-2.00)$ & 0.066 & 0.930 & $1.03(0.49-2.19)$ & 0.067 & 0.935 & $1.04(0.41-2.65)$ \\
\hline
\end{tabular}

OR odds ratio, $\mathrm{Cl}$ confidence interval; Ref: control by heterozygous genotypes and rare homozygous

\section{Meta-analysis of FSHR gene polymorphisms in infertile men}

A total of 15 studies, 4 studies from Asian population $[24,28-30]$ and 11 studies from non-Asian population $[1,13,14,16,17,22,31-35]$, met the inclusion criteria (Fig. 1). Including our study, the main characteristics of 12 case-control studies (2903 controls and 2564 cases) on the rs6165, 16 studies (4320 controls and 3728 cases) on the rs6166, and 7 studies on the rs1394205 (2776 controls and 2048 cases) were showed in Table 4. To determine the SNPs, three different genotyping methods were applied, including TaqMan assays, sequencing and PCR-RFLP. In addition, the sources of controls of these studies were mainly hospital population. The distribution of genotypes in the controls of HWE by the
Gharesi-Fard et al. 2015 [13], Pengo et al., 2006 [22], Balkan et al., 2010 [17] and Ghirelli-Filho et al., 2012 [1] reported, were $<0.05$, which were divided into subgroup in this meta-analysis.

For rs6165 polymorphism, the overall analyses showed that AG genotype was associated with increased risk of male infertility (OR: 1.15, 95\%CI: $1.02-1.30, P: 0.021$ ). In addition, in the subgroup analysis with HWE $>0.05$, significant differences was observed for the genotype GG (GG vs. AA, OR:1.26, 95\%CI:1.03-1.54, P:0.023), AG (AG vs. AA, OR:1.18, 95\%CI:1.03-1.36, P:0.018) and GA + GG (GA + GG vs. AA, OR:1.20, 95\%CI:1.05-1.37, $P$ : 0.006). By the race, one paper which reported in the Brazilian population, revealed a significant association for the comparison of AG vs. AA (OR: 1.81, 95\%CI:

Table 3 Haplotype analysis of the FSHR three SNPs rs6165, rs6166 and rs1394205

\begin{tabular}{|c|c|c|c|c|c|c|c|c|c|c|}
\hline \multirow[t]{2}{*}{ Haplotype } & \multirow{2}{*}{$\begin{array}{l}\text { Control } \\
(n=340) \\
\text { Frequency }\end{array}$} & \multicolumn{3}{|c|}{ Case $(n=255)$} & \multicolumn{3}{|c|}{$\begin{array}{l}\text { Sperm concentration }\left(<5 \times 10^{6} / \mathrm{ml}\right) \\
(n=166)\end{array}$} & \multicolumn{3}{|c|}{$\begin{array}{l}\text { Sperm concentration }\left(5-15 \times 10^{6} / \mathrm{ml}\right) \\
(n=89)\end{array}$} \\
\hline & & Frequency & $P$ & OR(95\%Cl) & Frequency & $P$ & OR(95\%Cl) & Frequency & $P$ & $\mathrm{OR}(95 \% \mathrm{Cl})$ \\
\hline \multicolumn{11}{|c|}{ FSHR rs1394205/rs6165/rs6166 } \\
\hline AAA & 0.376 & 0.382 & 0.794 & $1.03(0.81-1.31)$ & 0.366 & 0.652 & $0.94(0.72-1.23)$ & 0.427 & 0.163 & $1.27(0.91-1.79)$ \\
\hline AGG & 0.121 & 0.133 & 0.539 & $1.11(0.79-1.57)$ & 0.146 & 0.308 & $1.22(0.83-1.79)$ & 0.100 & 0.467 & $0.82(0.48-1.41)$ \\
\hline GAA & 0.309 & 0.269 & 0.133 & $0.82(0.64-1.06)$ & 0.287 & 0.408 & $0.89(0.66-1.18)$ & 0.219 & 0.022 & $0.63(0.43-0.94)$ \\
\hline GGG & 0.161 & 0.181 & 0.351 & $1.16(0.85-1.57)$ & 0.170 & 0.764 & $1.06(0.74-1.50)$ & 0.209 & 0.111 & $1.40(0.92-2.13)$ \\
\hline \multicolumn{11}{|c|}{ FSHR rs6165/rs6166 } \\
\hline AA & 0.685 & 0.669 & 0.430 & $0.92(0.74-1.14)$ & 0.653 & 0.256 & $0.85(0.64-1.13)$ & 0.678 & 0.729 & $0.96(0.76-1.22)$ \\
\hline GG & 0.282 & 0.296 & 0.579 & $1.06(0.86-1.32)$ & 0.317 & 0.256 & $1.18(0.89-1.57)$ & 0.285 & 0.946 & $1.01(0.79-1.29)$ \\
\hline
\end{tabular}




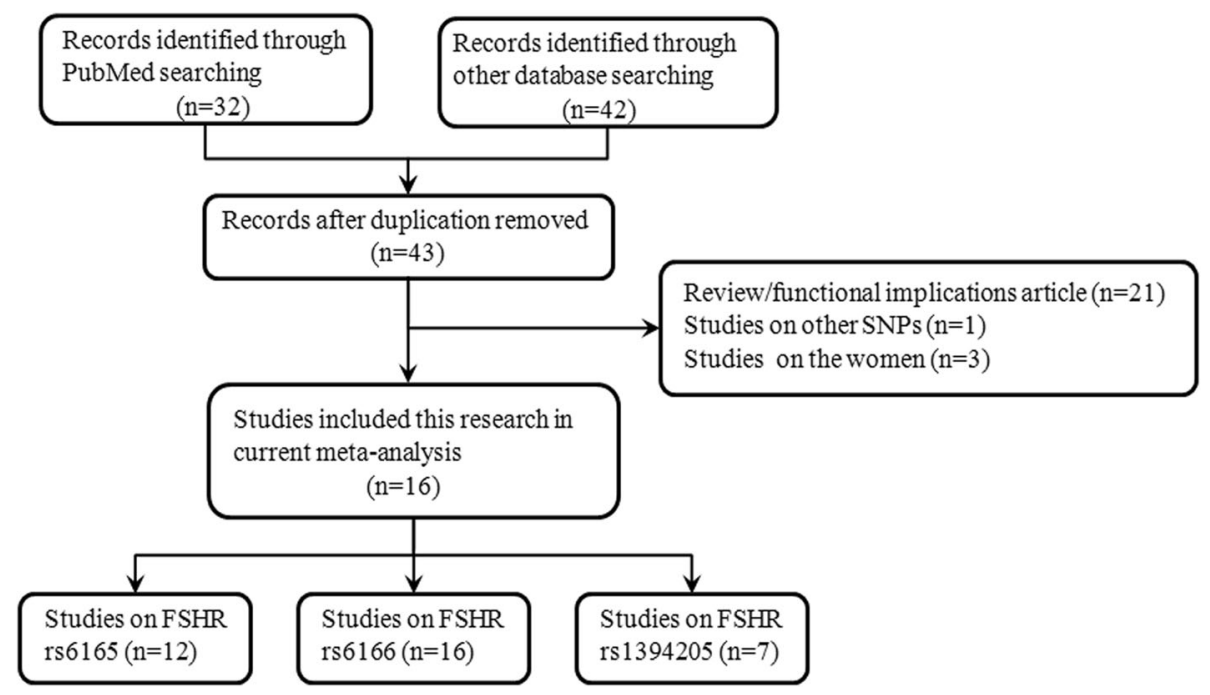

Fig. 1 Flow chart of studies identified with inclusion and exclusion criteria

1.08-3.31, P: 0.023), GA + GG vs. AA (OR: 1.65, 95\%CI: 1.02-2.67, P: 0.042). And a slight significant association for the AG vs. AA (OR: 1.17, 95\%CI: 1.00-1.36, P: 0.047) was found in the subgroup analysis of case count $>200$. However, no significant association was revealed in the remaining subgroup analyses, as summarized in Table 5, Fig. 2.

For rs6166 polymorphism, no significant association was observed under the all genetic models in overall analyses; however, significant differences was showed for the comparison of GG vs. AA (OR:1.24, 95\%CI:1.051.45, P: 0.009), GG vs. AA + AG (OR:1.20, 95\%CI:1.04$1.39, P: 0.013)$ in subgroup analysis with $\mathrm{HWE}>0.05$, and the comparison of GG vs. AA (OR:1.18, 95\%CI:1.00-1.38, P:0.047) in subgroup analysis with case count $>200$, as presented in Table 5, Fig. 3.

For rs1394205 polymorphism, no significant association was showed in overall analyses and subgroup analyses.

\section{Test of heterogeneity and sensitivity analysis}

Sensitivity analyses on the FSHR SNPs rs6165, rs6166 and rs1394205 under four models were conducted. Among rs6165 polymorphism, we found slight heterogeneity for the comparison of dominant model (GA + GG vs. AA: $\left.P_{h}: 0.042\right)$ in overall analysis, homozygote model (GG vs. AA: $P_{h}$ : 0.038), dominant model (GA + GG vs. AA: $\left.P_{h}: 0.044\right)$ in subgroup analysis of case count $>200$. The heterogeneity was decreased respectively to 0.120 , 0.266 and 0.201 when omitting the paper reported by Gharesi-Fard et al. [13]. Among rs1394205 polymorphisms, a significant heterogeneity was apparent in the overall analyses under the homozygote model, heterozygous model and dominant model. Consistently, subgroup analyses by HWE, race and case count for rs1394205 also showed a significant heterogeneity, which indicated in Table 5. Sensitivity analysis revealed that the study reported by Li Y et al. [28], was the origin of substantial heterogeneity, and this was decreased when it was removed.

\section{Publication bias}

Begg's Funnel plots and Egger' test were performed to assess publication bias. For the FSHR rs6165, rs6166 and rs1394205 funnel plot shape did not show any evidence of obvious asymmetry in all comparison models. And the Egger's test was used to provide statistical evidence for funnel plot symmetry, which showed no obvious evidence of publication bias.

\section{Discussion}

In the present study, we included 340 fertile males and 255 infertile males, consisting of 166 with azoospermia or severe oligozoospermia, and 89 with oligospermia, and we investigated the association between $F S H B$, FSHR gene polymorphisms and male infertility. Compared with the fertile controls, the infertile patients had higher FSH and LH levels, and lower sperm concentration and sperm motility. Then the most common FSHR allelic variants in the core promoter and exon 10, and the FSHB variants in the core promoter were genotyped with respect to male infertility status using the Mass ARRAY platform. However, the distributions of FSHB and FSHR allele, genotype frequencies among azoospermic, severe oligozoospermic, or oligozoospermic men and fertile men based on age-adjusted estimates were similar. However a more precise analysis should be conducted if all individual raw data were available, to allow 
Table 4 Main characteristics of all studies on the genotype of FSHR rs6165, rs6166 and rs1394205 included in the meta-analysis

\begin{tabular}{|c|c|c|c|c|c|c|c|c|c|}
\hline Author & Year & Race & $\begin{array}{l}\text { Control } \\
\text { source }\end{array}$ & $\begin{array}{l}\text { Genotyping } \\
\text { methods }\end{array}$ & $\begin{array}{l}\text { Polymorphism } \\
\text { sites }\end{array}$ & $\begin{array}{l}\text { Control/ } \\
\text { Case } \\
\text { counts }\end{array}$ & $\begin{array}{l}\text { Genotype } \\
\text { counts } \\
\text { (control/ } \\
\text { case) }\end{array}$ & $\begin{array}{l}\text { HWE } \\
\text { (Control) }\end{array}$ & Clinical diagnosis of cases \\
\hline $\begin{array}{l}\text { Gharesi- } \\
\text { Fard B }\end{array}$ & 2015 & Caucasian & $\mathrm{HP}$ & PCR-RELP & $\begin{array}{l}\text { rs6165 } \\
\text { rs6166 }\end{array}$ & $200 / 212$ & $\begin{array}{l}\text { AA:47/64, } \\
\text { AG:85/91, } \\
\text { GG:68/57; } \\
\text { AA:40/33, } \\
\text { AG:107/128, } \\
\text { GG:53/51; }\end{array}$ & $\begin{array}{l}0.047 \\
0.291\end{array}$ & $\begin{array}{l}\text { This case control study was performed } \\
\text { on } 212 \text { primary azoospermic patients } \\
\text { and } 200 \text { healthy men. Azoospermia was } \\
\text { confirmed based on two separate } \\
\text { semen analysis. Inclusion criteria for } \\
\text { NOA were, having no history of genital } \\
\text { infections and existence of bilateral vas } \\
\text { deferens and the exclusion criteria were, } \\
\text { having history of surgery or vasectomy. } \\
\text { All OA cases were selected among men } \\
\text { with primary idiopathic epididymis } \\
\text { obstruction. Excluding criteria for OA } \\
\text { cases were azoospermia due vas } \\
\text { deferens or ejaculatory duct. Moreover, } \\
\text { patients with genital infections, } \\
\text { vasectomy, or other iatrogenic injuries } \\
\text { to the male reproductive tract were } \\
\text { excluded from the study. }\end{array}$ \\
\hline WuX & 2015 & Asian & $\mathrm{HP}$ & Sequence & $\begin{array}{l}\text { rs6165 } \\
\text { rs6166 }\end{array}$ & $164 / 212$ & $\begin{array}{l}\text { AA:80/95, } \\
\text { AG:75/95, } \\
\text { GG:9/22; } \\
\text { AA:82/100, } \\
\text { AG:72/92, } \\
\text { GG:10/20; }\end{array}$ & $\begin{array}{l}0.108 \\
0.261\end{array}$ & $\begin{array}{l}\text { The patients selected consisted of } \\
\text { infertile men with idiopathic infertility } \\
\text { ranging from oligospermia to } \\
\text { azoospermia. Other diseases that could } \\
\text { cause secondary infertility, such as } \\
\text { obstructive azoospermia, karyotype } \\
\text { abnormalities, Y chromosome } \\
\text { microdeletions, and cryptorchidism, } \\
\text { were excluded. The controls consisted } \\
\text { of normospermic patients who were } \\
\text { from couples suffering infertility due to } \\
\text { the woman's issues and no genetic or } \\
\text { reproductive tract disease. }\end{array}$ \\
\hline Grigorova M & 2014 & Caucasian & PB & Sequence & rs1394205 & $982 / 641$ & $\begin{array}{l}\text { GG:552/380, } \\
\text { AG:362/228, } \\
\text { AA:68/33 }\end{array}$ & 0.412 & $\begin{array}{l}\text { The inclusion criterion for male partners } \\
\text { of infertile couples entering the study } \\
\text { was sperm concentration below } \\
20 \times 10^{6} / \mathrm{ml} \text {. All men with causal factors } \\
\text { for male factor infertility (obstruction, } \\
\text { cryptorchidism, chromosomal } \\
\text { abnormalities, Y chromosome deletions, } \\
\text { hypogonadotrophic hypogonadisn, } \\
\text { testicular diseases, sexual dysfunctions, } \\
\text { androgen abuse, severe traumas and } \\
\text { operation in genital area, chemo- and } \\
\text { radio- therapy) were excluded. }\end{array}$ \\
\hline Grigorova M & 2013 & Caucasian & $\mathrm{HP}$ & PCR-RELP & rs6166 & $1052 / 738$ & $\begin{array}{l}\text { AA:379/261, } \\
\text { AG:506/353, } \\
\text { GG:167/124; }\end{array}$ & 0.930 & $\begin{array}{l}\text { The inclusion criterion for male partners } \\
\text { of infertile couples entering the study } \\
\text { was sperm concentration below } \\
20 \times 10^{6} / \mathrm{ml} \text {. All men with causal factors } \\
\text { for male factor infertility (obstruction, } \\
\text { cryptorchidism, chromosomal } \\
\text { abnormalities, Y chromosome deletions, } \\
\text { hypogonadotrophic hypogonadisn, } \\
\text { testicular diseases, sexual dysfunctions, } \\
\text { androgen abuse, severe traumas and } \\
\text { operation in genital area, chemo- and } \\
\text { radio- therapy) were excluded. }\end{array}$ \\
\hline Lazaros L & 2013 & Caucasian & $\mathrm{HP}$ & PCR-RELP & $\begin{array}{l}\text { rs6165 } \\
\text { rs6166 }\end{array}$ & $250 / 200$ & $\begin{array}{l}\text { AA:65/49, } \\
\text { AG:132/92, } \\
\text { GG:53/59; } \\
\text { AA:65/49, } \\
\text { AG:132/92, } \\
\text { GG:53/59; }\end{array}$ & $\begin{array}{l}0.356 \\
0.356\end{array}$ & $\begin{array}{l}\text { The study population was consisted of } \\
450 \text { Greek men, } 250 \text { normozoospermic } \\
\text { and } 200 \text { oligozoospermic men, who } \\
\text { were referred to the in vitro fertilization } \\
\text { (IVF) Unit, which was based on World } \\
\text { Health Organization criteria (WHO, 1999). }\end{array}$ \\
\hline
\end{tabular}


Table 4 Main characteristics of all studies on the genotype of FSHR rs6165, rs6166 and rs1394205 included in the meta-analysis (Continued)

\begin{tabular}{|c|c|c|c|c|c|c|c|c|c|}
\hline Song $D$ & 2013 & Asian & $\mathrm{HP}$ & Sequence & $\begin{array}{l}\text { rs6165 } \\
\text { rs6166 }\end{array}$ & $200 / 150$ & $\begin{array}{l}\text { AA:81/65, } \\
\text { AG:88/63, } \\
\text { GG:31/22; } \\
\text { AA: } 86 / 69 \\
\text { AG:87/58, } \\
\text { GG:27/23; }\end{array}$ & $\begin{array}{l}0.386 \\
0.506\end{array}$ & $\begin{array}{l}\text { Inclusion criteria were as follows: (I) } \\
\text { diagnosed as idiopathic infertility or } \\
\text { severe oligoasthenozoospermic (ii) } \\
\text { sperm count below } 10 \times 10^{6} / \mathrm{ml} \text {, sperm } \\
\text { motility }(\mathrm{a}+\mathrm{b})=1.19 \%-9.99 \% \text { and } \\
\text { normal sperm morphology }>4 \% \text { as } \\
\text { determined by at least three semen } \\
\text { analyses. Patients were excluded if they } \\
\text { had: (I) hypogonadotrophic } \\
\text { hypogonadism or abuse of androgenic } \\
\text { (anabolic) steroids (ii) obstructive } \\
\text { azoospermia (iii) underwent treatment } \\
\text { with chemotherapeutic agents or } \\
\text { radiotherapy. Azoospermic and severely } \\
\text { oligozoospermic men with karyotype } \\
\text { abnormalities and Y chromosome long } \\
\text { arm microdeletions were excluded. }\end{array}$ \\
\hline $\begin{array}{l}\text { Ghirelli- } \\
\text { Filho M }\end{array}$ & 2012 & Brazilian & $\mathrm{HP}$ & Taqman & $\begin{array}{l}\text { rs6165 } \\
\text { rs6166 }\end{array}$ & $217 / 138$ & $\begin{array}{l}\text { AA:74/33, } \\
\text { AG:89/72, } \\
\text { GG:54/33; } \\
\text { AA: 49/32, } \\
\text { AG:88/66, } \\
\text { GG:80/40; }\end{array}$ & $\begin{array}{l}0.011 \\
0.011\end{array}$ & $\begin{array}{l}\text { Infertile men with severe } \\
\text { oligozoospermia (SO) and non- } \\
\text { obstructive azoospermia (NOA), with at } \\
\text { least } 1 \text { year of infertility were included } \\
\text { in this study. Individuals with known } \\
\text { causes of infertility including genetic } \\
\text { factors (chromosome anomalies, AZF } \\
\text { [azoospermia factor] microdeletions), } \\
\text { clinical factors (varicocele, cryptorchidism) } \\
\text { and men whose partner had factors } \\
\text { involved in infertility were excluded } \\
\text { from this study. To compose the } \\
\text { control group, } 217 \text { fertile men, who } \\
\text { have at least } 2 \text { children by direct } \\
\text { survey and who lacked any history of } \\
\text { requiring assisted reproduction } \\
\text { technology, were selected. }\end{array}$ \\
\hline $\operatorname{LiY}$ & 2011 & Asian & $\mathrm{HP}$ & PCR-RELP & $\begin{array}{l}\text { rs6165 } \\
\text { rs6166 } \\
\text { rs1394205 }\end{array}$ & $469 / 176$ & $\begin{array}{l}\text { AA:189/75, } \\
\text { AG:230/88, } \\
\text { GG:50/13; } \\
\text { AA:203/80, } \\
\text { AG:220/82, } \\
\text { GG:46/14; } \\
\text { GG:118/101, } \\
\text { AG:250/96, } \\
\text { AA:101/38 }\end{array}$ & $\begin{array}{l}0.103 \\
0.221 \\
0.144\end{array}$ & $\begin{array}{l}\text { Those with a history of orchitis, } \\
\text { cryptorchidism, varicocoele, obstruction } \\
\text { of vas deferens, karyotype abnormality, } \\
\text { and Y chromosome microdeletions } \\
\text { were excluded. Additionally, subjects } \\
\text { having special occupational exposure } \\
\text { which may be suspected to affect } \\
\text { semen quality (such as pesticides or } \\
\text { other agents) were precluded. Then } 364 \\
\text { idiopathic infertile patients were divided } \\
\text { into three groups: } 97 \text { males with non- } \\
\text { obstructive azoospermia, } 79 \text { with } \\
\text { oligozoospemia (sperm count }<40 \times 10^{6} \% \\
\text { ejaculum), } 188 \text { with normozoospermia } \\
\text { (sperm count } \geq 40 \times 10^{6} / \text { ejaculum). } \\
\text { The control group consisted of } 285 \\
\text { subjects with normal semen parameters, } \\
\text { all of which had fathered at least one } \\
\text { child without assisted reproductive } \\
\text { technologies. }\end{array}$ \\
\hline $\begin{array}{l}\text { Safarinejad } \\
\text { MR }\end{array}$ & 2011 & Caucasian & $\mathrm{HP}$ & PCR-RELP & $\begin{array}{l}\text { rs6165 } \\
\text { rs6166 }\end{array}$ & $172 / 172$ & $\begin{array}{l}\text { AA:78/62, } \\
\text { AG:74/90, } \\
\text { GG:20/20; } \\
\text { AA: } 85 / 69 \\
\text { AG:72/80, } \\
\text { GG:15/23; }\end{array}$ & $\begin{array}{l}0.702 \\
0.964\end{array}$ & $\begin{array}{l}\text { All the infertile patients had to have a } \\
\text { history of primary infertility for at least } \\
24 \text { months with no known etiology for } \\
\text { their infertility. A history of the } \\
\text { following: cryptorchidism, varicocele, } \\
\text { testicular torsion or genital surgery; } \\
\text { azoospermia; UTIs; any endocrinopathy; } \\
\text { Y chromosome microdeletions or } \\
\text { karyotype abnormalities; use of } \\
\text { cytotoxic drugs, immunosuppressants, }\end{array}$ \\
\hline
\end{tabular}


Table 4 Main characteristics of all studies on the genotype of FSHR rs6165, rs6166 and rs1394205 included in the meta-analysis (Continued)

\begin{tabular}{|c|c|c|c|c|c|c|c|c|}
\hline Balkan M & 2010 & Caucasian & $\mathrm{HP}$ & PCR-RELP & $\begin{array}{l}\text { rs6166 } \\
\text { rs1394205 }\end{array}$ & $240 / 270$ & $\begin{array}{l}\text { AA:154/176, } \\
\text { AG:49/59, } \\
\text { GG:37/35; } \\
\text { GG:178/203, } \\
\text { AG:49/53, } \\
\text { AA:13/14 }\end{array}$ & $\begin{array}{l}0.000 \\
0.001\end{array}$ \\
\hline Lend AK & 2010 & Caucasian & $\mathrm{HP}$ & PCR-RELP & $\begin{array}{l}\text { rs6165 } \\
\text { rs6166 } \\
\text { rs1394205 }\end{array}$ & $208 / 150$ & $\begin{array}{l}\text { AA:67/50, } \\
\text { AG:106/72, } \\
\text { GG:35/28; } \\
\text { AA:66/50, } \\
\text { AG:107/73, } \\
\text { GG:35/27; } \\
\text { GG: } 110 / 78, \\
\text { AG:85/61, } \\
\text { AA:13/11 }\end{array}$ & $\begin{array}{l}0.526 \\
0451 \\
0.522\end{array}$ \\
\hline Shimoda C & 2009 & Asian & $\mathrm{HP}$ & PCR-RELP & $\begin{array}{l}\text { rs6165 } \\
\text { rs6166 }\end{array}$ & $146 / 343$ & $\begin{array}{l}\text { AA:68/118, } \\
\text { AG:61/179, } \\
\text { GG:17/46; } \\
\text { AA:72/131, } \\
\text { AG:62/164, } \\
\text { GG:12/45; }\end{array}$ & $\begin{array}{l}0.560 \\
0.791\end{array}$ \\
\hline Zalata AA & 2008 & Caucasian & $\mathrm{HP}$ & PCR-RELP & rs6166 & $30 / 52$ & $\begin{array}{l}\text { AA: 14/18, } \\
\text { AG:10/20, } \\
\text { GG:6/14; }\end{array}$ & 0.122 \\
\hline Pengo M & 2006 & Caucasian & $\mathrm{HP}$ & PCR-RELP & $\begin{array}{l}\text { rs6165 } \\
\text { rs6166 } \\
\text { rs1394205 }\end{array}$ & $351 / 215$ & $\begin{array}{l}\text { AA:114/75, } \\
\text { AG:153/96, } \\
\text { GG:84/44; } \\
\text { AA:114/75, } \\
\text { AG:153/96, } \\
\text { GG:84/44; } \\
\text { GG:203/126, } \\
\text { AG:121/73, } \\
\text { AA:27/16 }\end{array}$ & $\begin{array}{l}0.022 \\
0.023 \\
0.139\end{array}$ \\
\hline
\end{tabular}

anticonvulsives, androgens or antiandrogens; leukocytospermia (more than 106 white blood cells per $\mathrm{mL}$ ), or a positive mixed agglutination reaction test were exclusion criteria. Participants with a history of hepatobiliary disease, significant renal insufficiency, drug or alcohol abuse or dependence, tobacco use, occupational and environmenta exposures to potential reproductive toxins, and a body mass index (BMI) of $\geq 30 \mathrm{~kg} / \mathrm{m}^{2}$ were also excluded.

The study population consisted of 240 proven fathers (sperm count $>20 \times 10^{6} / \mathrm{ml}$ and serum FSH levels $<7 \mathrm{IU} / \mathrm{L}$ ), and infertile men (150 non-obstructive azoospermic and 120 severe oligozoospemic in which sperm count $<10 \times 10^{6} / \mathrm{ml}$ ). And karyotype abnormalities and $Y$ chromosome microdeletions were exclusion criteria.

Patients with non-obstructive idiopathic azoospermia $(n=36)$ or oligozoospermia (sperm count $<20 \times 10^{6} / \mathrm{ml}, n=114$ ) and without any obvious cause of infertility were considered as infertile cases for the study. The controls group consisted of 208 military conscripts selected based on their sperm count of $\geq 75 \times 10^{6} / \mathrm{ml}$.

All patients presented with nonobstructive azoospermia and elevated basal FSH concentrations ( $>10.0 \mathrm{mlU} / \mathrm{mL}$ ), without $Y$ chromosome microdeletion and normal karyotypes. Fertility status was proven by the fact that each of the control subjects had fathered one or more children.

The 82 Caucasian men were divided into group (gp)1 $(n=30)$ normozoospermic, fertile and healthy volunteers who had achieved conception with 1 year, and gp2 $(n=52)$ infertile oligoasthenozoospermic males. Exclusion criteria were varicocele, cryptorchidism, karyotype anomalies, Y chromosome microdeletions and leucocytospermia.

Inclusion criteria were as follows: (i) a minimum of 1 year of infertility (ii) sperm count below $20 \times 106 / \mathrm{ml}$ as determined by at least two semen analyses. Patients were excluded if they had: (i) hypogonadotrophic hypogonadism or abuse of androgenic (anabolic) steroids (ii) obstructive azoospermia (iii) undergone treatment with chemotherapeutic agents or radiotherapy. Azoospermic and severely oligozoospermic men with karyotype abnormalities and $Y$ chromosome long arm microdeletions were excluded. 
Table 4 Main characteristics of all studies on the genotype of FSHR rs6165, rs6166 and rs1394205 included in the meta-analysis (Continued)

\begin{tabular}{|c|c|c|c|c|c|c|c|c|c|}
\hline Galan J J & 2005 & Caucasian & PB & PCR-RELP & rs6166 & $95 / 104$ & $\begin{array}{l}\text { AA:26/38, } \\
\text { AG:51/49, } \\
\text { GG:18/17; }\end{array}$ & 0.428 & $\begin{array}{l}104 \text { Caucasoid men with idiopathic } \\
\text { non-obstructive oligozoospermia or } \\
\text { azoospermia (sperm counts }<5 \times 10^{6} \% \\
\text { ml) were recruited during this work, } \\
\text { which did not consider Y chromosome } \\
\text { microdeletions as a confounding factor } \\
\text { because of the low frequency of Y } \\
\text { chromosome microdeletions. }\end{array}$ \\
\hline Ahda Y & 2005 & Caucasian & PB & Taqman & $\begin{array}{l}\text { rs6165 } \\
\text { rs6166 } \\
\text { rs1394205 }\end{array}$ & $186 / 341$ & $\begin{array}{l}\text { AA:74/101, } \\
\text { AG:77/166, } \\
\text { GG:35/74; } \\
\text { AA:74/101, } \\
\text { AG:77/166, } \\
\text { GG:35/74; } \\
\text { GG:102/164, } \\
\text { AG:74/150, } \\
\text { AA:10/27 }\end{array}$ & $\begin{array}{l}0.068 \\
0.068 \\
0.466\end{array}$ & $\begin{array}{l}\text { The study population consisted of } 186 \\
\text { men with normal semen values } \\
\text { according to WHO criteria (1999) and } \\
\text { normal serum FSH levels }(<7 \mathrm{IU} / \mathrm{L}) \text {, } \\
\text { recruited for contraceptve trials through } \\
\text { advertisement in the local newspaper, } \\
\text { and } 341 \text { infertile men with } \\
\text { nonobstructive azoospermia and } \\
\text { elevated FSH levels ( } \geq 7 \mathrm{IU} / \mathrm{L} \text { ) attending } \\
\text { our infertility clinic. Hypogonadotropic } \\
\text { hypogonadism and genetic defects } \\
\text { causing azoospemia (Klinefelter } \\
\text { syndrome or deletions of the Y } \\
\text { chromosome) were exclusion criteria. }\end{array}$ \\
\hline This study & 2016 & Asian & $\mathrm{HP}$ & Mass-array & $\begin{array}{l}\text { rs6165 } \\
\text { rs6166 } \\
\text { rs1394205 }\end{array}$ & $340 / 255$ & $\begin{array}{l}\text { AA:163/210, } \\
\text { AG:144/199, } \\
\text { GG:33/52; } \\
\text { AA:169/230, } \\
\text { AG:146/187, } \\
\text { GG:25/44; } \\
\text { GG:78/112, } \\
\text { AG:170/233, } \\
\text { AA:92/116 }\end{array}$ & $\begin{array}{l}0.884 \\
0.391 \\
0.975\end{array}$ & 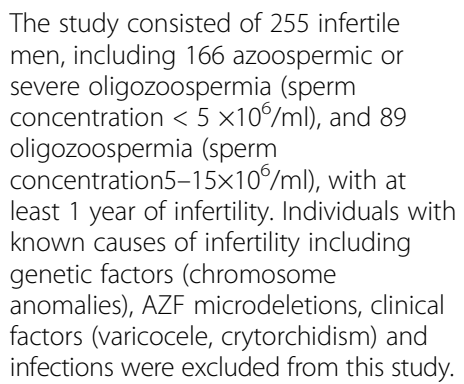 \\
\hline
\end{tabular}

for the adjustment according to hormone, sperm parameters and other lifestyle factors. Consistent with previous reportes [31, 34], we also identified a significant association for the comparison of GAA (P: 0.022, OR: 0.63, 95\% CI: 0.43-0.94) among the oligozoospermic men in haplotype analysis, which indicated that the GAA haplotype would exert protective effects against male sterility.

Previous studies examining potential associations between FSHR polymorphisms and male infertility parameters have produced contradictory results. Variants of FSHR have been shown to affect the serum FSH, inhibin $\mathrm{B}$, anti-Mullerian hormone (AMH) and total testes volume $[5,14,25,33]$. However, the majority of studies have failed to detect any link between common FSHR isoforms and male reproductive parameters. It is regrettable that not all clinical fertility parameters in this study were collected, as we could not find any association between the clinical fertility parameters and the FSHB and FSHR genotypes.

FSH secreted by the anterior pituitary, together with other endocrine factors, plays a central role in establishing and maintaining human fertility. In males, circulating FSH stimulates gametogenesis and steroidogenesis in the gonads by binding to its receptor (FSHR). Tuttelmann et al. reported that the FSHB $-211 \mathrm{G}>\mathrm{T}$ T-allele showed significant dosage effects on FSH, LH and bilateral testicular volume. Moreover, FSHR 2029A > G significantly modulated the more dominant effect of FSHB -211G > T on serum FSH and testicular volume among the T-allele carriers [18], suggesting that the interplay between polymorphisms in hormone and receptor is of relevance under physiological conditions.

We searched available databases, such as GWAS Central, National Human Genome Research Institute GWAS Catalog and PUBMED, but failed to find a relevant genome-wide association study (GWAS) on all SNPs. To date, no clear consensus appears to have been reached in the literature on the relationship between FSHR polymorphisms and male infertility risk.

To resolve the conflicting results, we carried out a meta-analysis to obtain a more precise estimation of the associations. Contrary to previous meta-analyses that found no significant association between FSHR rs1394205 (G-29A), rs6165 (Thr307Ala), or rs6166 (Asn680Ser) polymorphisms and the risk of male 


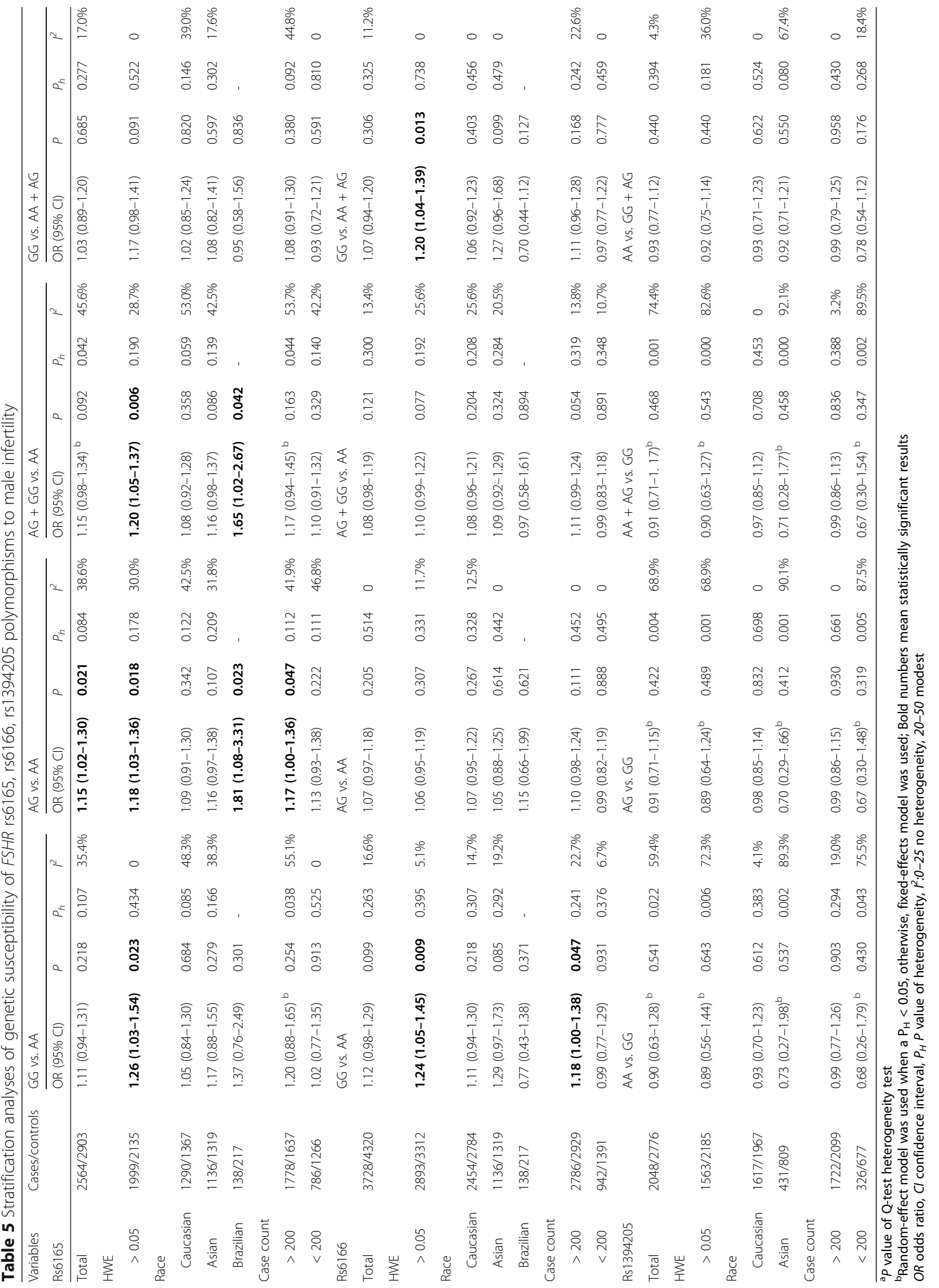




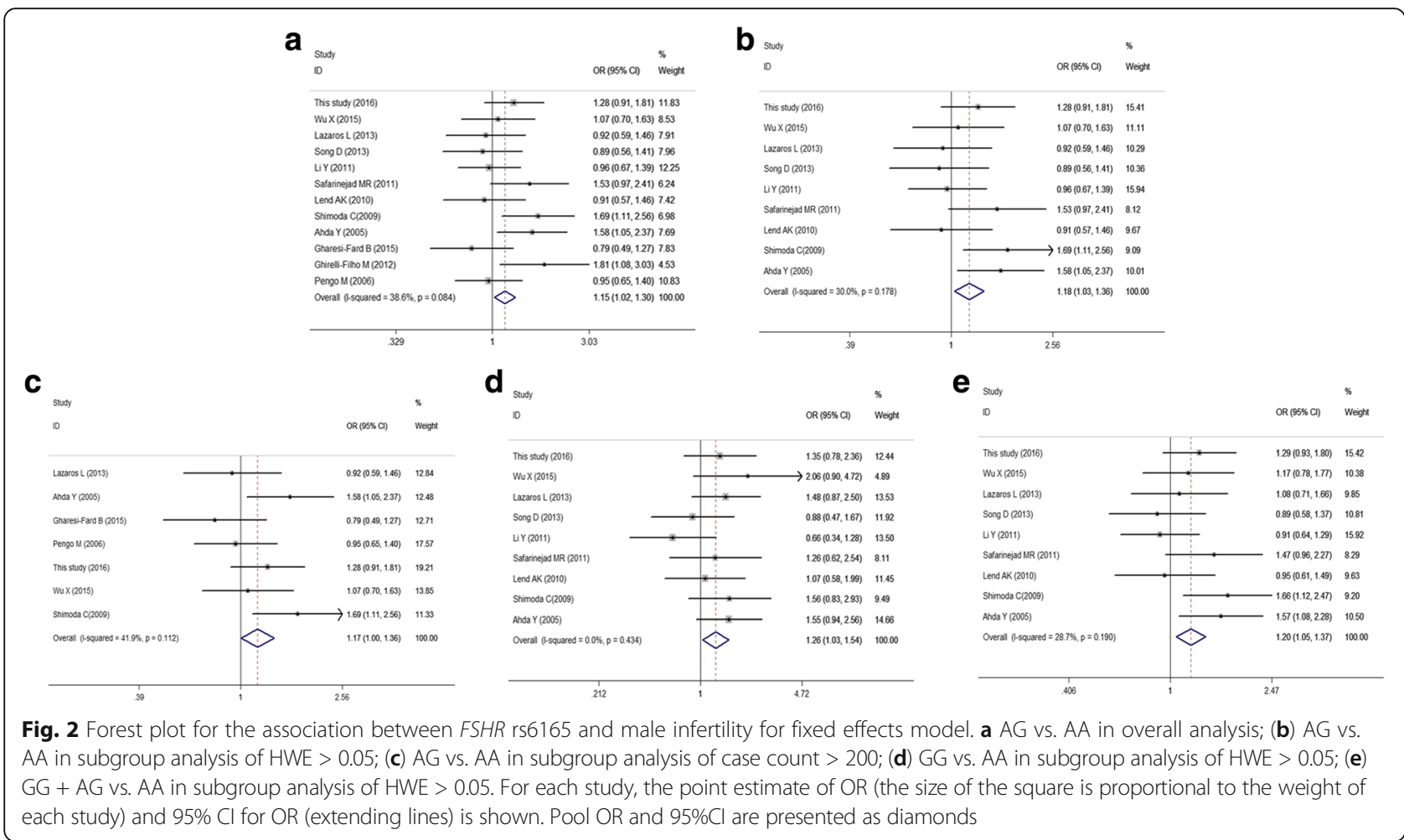

infertility [2, 30, 34], this study indicated that the rs6165G allele was associated with increased risk of male infertility, particularly in the subgroup analysis of HWE > 0.05. In addition the rs6166 GG genotype was also observed to be a risk factor for infertility in the subgroup analysis of HWE $>0.05$. One possible reason for these discrepant findings is specific selection of the publications. However, the FSHR rs1394205 polymorphism was not associated with male infertility, which was similar to the findings of other studies.

In addition, identifying the source of heterogeneity is one of the most important goals of the meta-analysis. In each case, the heterogeneity could be a result of differences in ethnicity, sources of controls, methods used and so on. In this study, we found that significant heterogeneity existed in overall analysis and sub-group analysis for the comparison of FSHR rs1394205 polymorphisms and male infertility. Sensitivity analysis revealed that the study reported by $\mathrm{Li}$ et al. [28], contained substantial heterogeneity, and this was decreased when it was removed. The subjects of the casecontrol study by Li et al. [28], comprised 364 idiopathic infertile patients (97 with non-obstructive azoospermia, 79 with oligozoospermia and 188 with normozoospermia) and 285 fertile men were collected [28]. However, previouslyreported meta-analyses including our meta-analysis considered 188 men with normozoospermia and 285 fertile men as controls, which brought out different associations between the FSHR rs1394205A allele and male infertility, resulting in the significant heterogeneity.
It should be pointed out that there are some limitations in this meta-analysis. Firstly, inadequate sample size and inappropriate control subjects resulted in limited power for exploring the real association, and subgroup analyses by HWE, ethnicity, and case count involved relatively small groups, which were more likely to reveal greater beneficial effects than a large-scale trial. Secondly, owing to lack of the original data, we could not further evaluate the potential interactions between genes, which might affect male infertility. Thirdly, much detailed information, including body mass index, age, work, smoking or alcohol habits, environmental exposure and other lifestyle factors, is not available, so that our results were based on unadjusted estimates. A more precise analysis should be conducted through adjustment by other co-variants. In fact, some other genes as well as environmental exposure could also play an important role in spermatogenesis.

Owing to the critical role of FSH in spermatogenesis, polymorphisms in the FSHB and FSHR genes might disturb normal spermatogenesis and affect male reproductive ability. Because of this, FSH treatment has always been tempting and is actively prescribed by many doctors even though the efficacy of FSH therapy remains a contentious issue. One study showed that patients with at least one FSHR c.2039A > G G allele had a significant increase in total sperm count after 3 months of treatment with recombinant FSH (rFSH, $150 \mathrm{IU} /$ three times per week). Another study considered the FSHB-211G > T genotype and showed that 


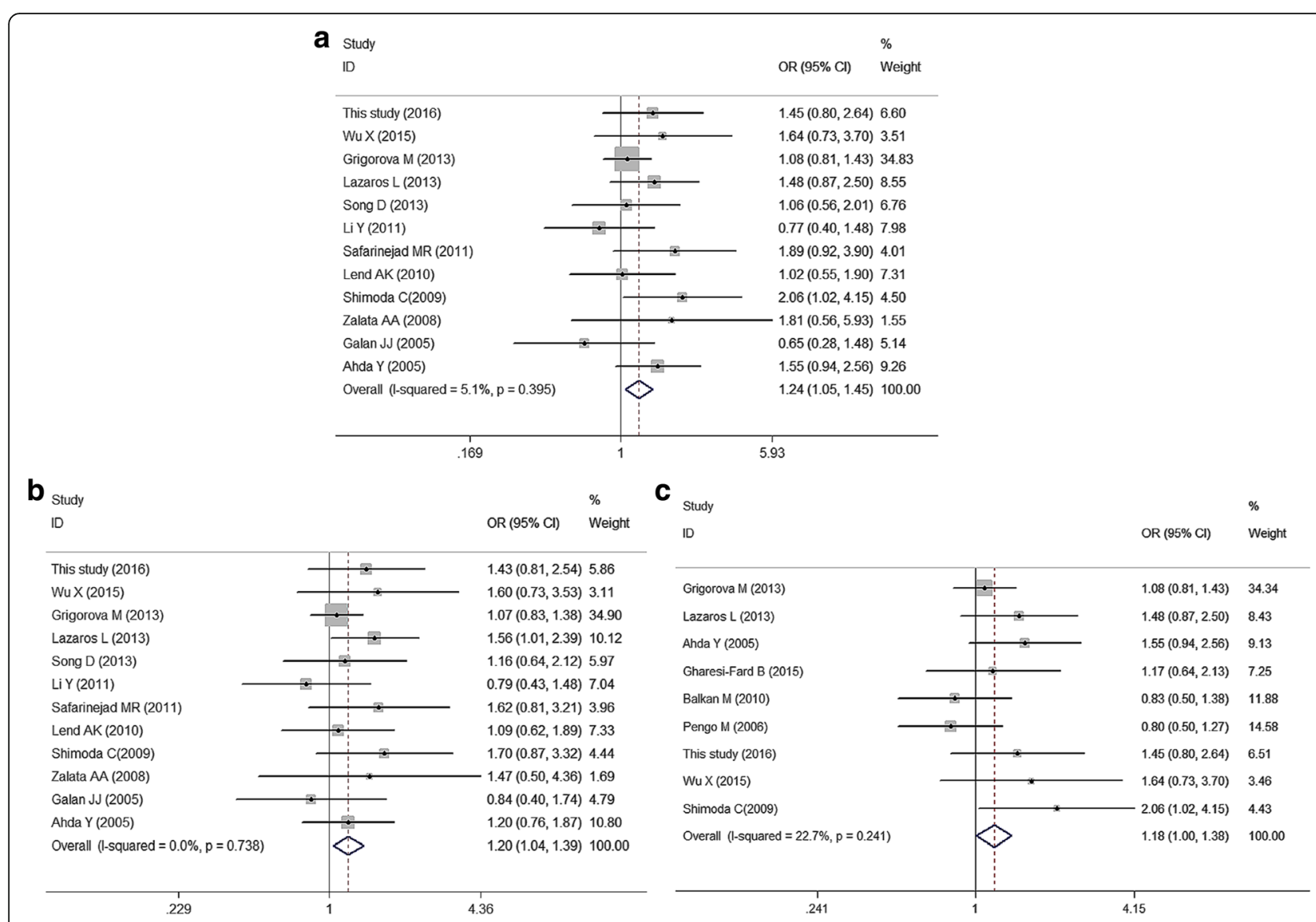

Fig. 3 Meta-analysis of male infertility risk associated with FSHR rs6166 for fixed effects model. a GG vs. AA in subgroup analysis of HWE > 0.05; (b) GG vs. AA + AG in subgroup analysis of HWE > 0.05; (c) GG vs. AA in subgroup analysis of case count > 200

TT homozygote, representing $25 \%$ of men with oligozoospermia and low FSH levels, could significantly benefit from FSH treatment [23]. However, there have been other studies showing that the outcome of FSH treatment was poor. Possible reasons include that the doses used were too low, with a high dose of recombinant rFSH necessary for treatment to be effective. Another explanation is that FSH therapy might require stratification of men according to genotype into FSH-responsive and non-responsive individuals, which depending on the FSHB and FSHR genotypes [36].

\section{Conclusions}

This study suggested that FSHR GAA haplotype would exert protective effects against male sterility, which indicated that the combination of three SNP genotypes of FSHR was predicted to have a much stronger impact than either one alone. Then in the meta-analysis, a significant association was seen between FSHR rs6165, rs6166 polymorphisms and male infertility. In terms of male infertility with multifactorial etiology, further studies with larger sample sizes and different ethnic backgrounds or other risk factors are warranted to clarify the potential role of FSHB and FSHR polymorphisms in the pathogenesis of male infertility.

\section{Abbreviations}

AMH: Anti-Mullerian hormone; AR: Androgen receptor; Cl: Confidence interval; CNKI: Chinese national knowledge infrastructure; DAZL: Deleted in azoospermia like gene; DSD: Disorders of sexual development; E: Estradiol; FSHR: Follicle stimulating hormone receptor gene; FSHB: FSH beta subunit; GC: Granulosa cells; GWAS: Genome-wide association study; hGLC: Human granulosa-lutein cells; HWE: Hardy-Weinberg equilibrium; KS: Klinefelter syndrome; LH: Luteinizing hormone; MTHFR: Methylene- tetrahydrofolate reductive; OR: Odds ratio; SNP: Single nucleotide polymorphism;

T: Testosterone; vs.: Versus

\section{Acknowledgements}

We thank Dr. Bangshun He (Central Laboratory, Nanjing First Hospital, Nanjing Medical University, Jiangsu, China) for expert advice on metaanalysis. We additionally appreciate the valuable comments from other members of our laboratory.

\section{Funding}

This work was supported by Nanjing Science and Technology Project (201605004), Nanjing Science and Technology Development Project (201503010), Nanjing military Science and Technology Project (14MS098) and Foundation of Jinling Hospital of Nanjing University (2015046).

\section{Availability of data and materials}

The datasets used and/or analysed during the current study available from the corresponding author on reasonable request.

\section{Authors' contributions}

QYW, JZ and PRZ made substantial contributions to conception and design, acquisition of data, analysis and interpretation of data. WJJ, SML and MXN 
had been involved in drafting the manuscript or revising it critically for important intellectual content. MCZ, WWL and QZ agreed to be accountable for all aspects of the work in ensuring that questions related to the accuracy or integrity of any part of the work are appropriately investigated and resolved. XYX and YXC given final approval of the version to be published. Each author should have participated sufficiently in the work to take public responsibility for appropriate portions of the content. All authors read and approved the final manuscript.

\section{Ethics approval and consent to participate}

The manuscript has been read and approved by all the authors. The research adhered to the tenets of The Declaration of Helsinki. The Ethics Committee of Jinling Hospital approved the protocol. The patients gave written informed consent.

\section{Consent for publication}

Written informed consent about the patients for publication was obtained.

\section{Competing interests}

The authors declare that they have no competing interests.

\section{Publisher's Note}

Springer Nature remains neutral with regard to jurisdictional claims in published maps and institutional affiliations.

\section{Received: 15 December 2016 Accepted: 13 July 2017} Published online: 01 August 2017

\section{Reference}

1. Ghirelli-Filho M, Peluso C, Christofolini DM, Gava MM, Glina S, Barbosa CP, Bianco B. Variants in follicle-stimulating hormone receptor gene in infertile Brazilian men and the correlation to FSH serum levels and sperm count. Reprod Sci. 2012;19(7):733-9.

2. Wu W, Cai H, Sun H, Lu J, Zhao D, Qin Y, Han X, Niu X, Lu C, Xia Y. Follicle stimulating hormone receptor G-29A, 919A> G, 2039A> G polymorphism and the risk of male infertility: a meta-analysis. Gene. 2012;505(2):388-92.

3. Ferlin A, Arredi B, Foresta C. Genetic causes of male infertility. Reprod Toxicol. 2006;22(2):133-41.

4. Kurzawski M, Wajda A, Malinowski D, Kazienko A, Kurzawa R, Drozdzik M Association study of folate-related enzymes (MTHFR, MTR, MTRR) genetic variants with non-obstructive male infertility in a polish population. Genet Mol Biol. 2015;38(1):42-7

5. Gupta N, Sarkar S, David A, Gangwar PK, Gupta R, Khanna G, Sankhwar SN, Khanna A, Rajender S. Significant impact of the MTHFR polymorphisms and haplotypes on male infertility risk. PLoS One. 2013;8(7):e69180.

6. Zhang S, Tang Q, Wu W, Yuan B, Lu C, Xia Y, Ding H, Hu L, Chen D, Sha J: Association between DAZL polymorphisms and susceptibility to male infertility: systematic review with meta-analysis and trial sequential analysis. Sci Rep. 2014:4:4642.

7. Chen P, Wang X, Xu C, Xiao H, Zhang W-H, Wang X-H, Zhang X-H Association of polymorphisms of A260G and A386G in DAZL gene with male infertility: a meta-analysis and systemic review. Asian J Androl. 2016; 18(1):96.

8. Giagulli V, Carbone M, De Pergola G, Guastamacchia E, Resta F, Licchelli B, Sabbà C, Triggiani V. Could androgen receptor gene CAG tract polymorphism affect spermatogenesis in men with idiopathic infertility? J Assist Reprod Genet. 2014;31(6):689-97.

9. Jaiswal D, Sah R, Agrawal NK, Dwivedi U, Trivedi S, Singh K. Combined effect of GSTT1 and GSTM1 polymorphisms on human male infertility in north Indian population. Reprod Sci. 2012;19(3):312-6.

10. Salehi Z, Gholizadeh L, Vaziri H, Madani AH. Analysis of GSTM1, GSTT1, and CYP1A1 in idiopathic male infertility. Reprod Sci. 2012;19(1):81-5.

11. Xiong D-K, Chen H-H, Ding X-P, Zhang S-H, Zhang J-H. Association of polymorphisms in glutathione S-transferase genes (GSTM1, GSTT1, GSTP1) with idiopathic azoospermia or oligospermia in Sichuan, China. Asian J Androl. 2015;17(3):481

12. Krausz C, Chianese C. Genetic testing and counselling for male infertility. Curr Opin Endocrinol Diab Obes. 2014;21(3):244-50.

13. Gharesi-Fard B, Ghasemi Z, Shakeri S, Behdin S, Aghaei F, Malek-Hosseini Z. The frequency of follicle stimulating hormone receptor gene polymorphisms in Iranian infertile men with azoospermia. Iran J Reprod Med. 2015;13(11):673.

14. Grigorova M, Punab M, Poolamets O, Sõber S, Vihljajev V, Žilaitienè B, Erenpreiss J, Matulevičius V, Tsarev I, Laan M. Study in 1790 Baltic men: FSHR Asn680Ser polymorphism affects total testes volume. Andrology. 2013; 1(2):293-300.

15. Busch A, Kliesch S, Tüttelmann F, Gromoll J. FSHB-211G> T stratification for follicle-stimulating hormone treatment of male infertility patients: making the case for a pharmacogenetic approach in genetic functional secondary hypogonadism. Andrology. 2015;3(6):1050-3.

16. Lazaros L, Xita N, Takenaka A, Sofikitis N, Makrydimas G, Stefos T, Kosmas I, Zikopoulos K, Hatzi E, Georgiou I. Synergistic effect of follicle-stimulating hormone receptor and androgen receptor gene variants on semen quality. Andrologia. 2013;45(5):339-44.

17. Balkan M, Gedik A, Akkoc H, Izci Ay O, Erdal ME, Isi H, Budak T. FSHR single nucleotide polymorphism frequencies in proven fathers and infertile men in Southeast Turkey. Biomed Res Int. 2010;2010

18. Tüttelmann F, Laan M, Grigorova M, Punab M, Sober S, Gromoll J. Combined effects of the variants FSHB- 211G > T and FSHR 2039A> G on male reproductive parameters. J Clin Endocrinol Metab. 2012;97(10):3639-47.

19. Dai L, Zhao Z, Zhao R, Xiao S, Jiang H, Yue X, Li X, Gao Y, Liu J, Zhang J. Effects of novel single nucleotide polymorphisms of the FSH beta-subunit gene on semen quality and fertility in bulls. Anim Reprod Sci. 2009;114(1): $14-22$.

20. Rao MC, Midgley AR, Richards JS. Hormonal regulation of ovarian cellular proliferation. Cell. 1978;14(1):71-8.

21. Nieschlag E, Simoni M, Gromoll J, Weinbauer G. Role of FSH in the regulation of spermatogenesis: clinical aspects. Clin Endocrinol. 1999:51(2):139-46.

22. Pengo M, Ferlin A, Arredi B, Ganz F, Selice R, Garolla A, Foresta C. FSH receptor gene polymorphisms in fertile and infertile Italian men. Reprod BioMed Online. 2006;13(6):795-800

23. Simoni M, Casarini L. Mechanisms in endocrinology: genetics of FSH action: a 2014-and-beyond view. Eur J Endocrinol. 2014;170(3):R91-R107.

24. Shimoda C, KOh E, YaMaMOtO K, MatSui F, SuGiMOtO K, Sin H-S, Maeda Y, Kanaya J, Yoshida A, Namiki M. Single nucleotide polymorphism analysis of the folliclestimulating hormone (FSH) receptor in Japanese with male infertility: identification of codon combination with heterozygous variations of the two discrete FSH receptor gene. Endocr J. 2009:56(7):859-65.

25. Grigorova M, Punab M, Punab AM, Poolamets O, Vihljajev V, Žilaitienẻ B, Erenpreiss J, Matulevičius $\mathrm{V}$, Laan $\mathrm{M}$. Reproductive physiology in young men is cumulatively affected by FSH-action modulating genetic variants: FSHR29G/a and c. 2039 a/G, FSHB-211G/T. PLoS One. 2014;9(4):e94244.

26. He B, Pan Y, Xu Y, Deng Q, Sun H, Gao T, Wang S. Associations of polymorphisms in microRNAs with female breast cancer risk in Chinese population. Tumor Biol. 2015;36(6):4575-82.

27. He B-S, Pan Y-Q, Lin K, Ying H-Q, Wang F, Deng Q-W, Sun H-L, Gao T-Y, Wang SK. Evaluation the susceptibility of five polymorphisms in microRNA-binding sites to female breast cancer risk in Chinese population. Gene. 2015;573(1):160-5.

28. Li Y, Gu A, Yang H, Ding X, Ji G, Lu C, Xia Y, Song L, Wang X. FSH receptor gene polymorphisms in fertile and infertile Han-Chinese males. Clin Chim Acta. 2011:412(11):1048-52

29. Song D, Zhang ZF, Zhang HQ, Zhou WJ, Zhang Y, Xu YJ, Du J, Hui N. Association between FSHR gene polymorphisms and severe oligozoospermia in ChangSanjiao region. Reprod Contracept. 2013;33(005):294-9.

30. Wu X, Xu S, Wang Y, Li Q, Wang Z, Zhang C, Shen Y. FSHR gene Thr307Ala and Asn680Ser polymorphisms in infertile men: an association study in North China and meta-analysis. Gene Mol Res. 2015;14(2):5592.

31. Ahda Y, Gromoll J, Wunsch A, Asatiani K, Zitzmann M, Nieschlag E, Simoni M. Follicle-stimulating hormone receptor gene Haplotype distribution in Normozoospermic and Azoospermic men. J Androl. 2005;26(4):494-9.

32. Galan JJ, Buch B, Cruz N, Segura A, Moron FJ, Bassas L, Martinez-Pineiro L, Real LM, Ruiz A. Multilocus analyses of estrogen-related genes reveal involvement of the ESR1 gene in male infertility and the polygenic nature of the pathology. Fertil Steril. 2005:84(4):910-8.

33. Zalata A, Hassan A, Nada H, Bragais F, Agarwal A, Mostafa T. Folliclestimulating hormone receptor polymorphism and seminal anti-Müllerian hormone in fertile and infertile men. Andrologia. 2008:40(6):392-7.

34. Lend AK, Belousova A, Haller-Kikkatalo K, Punab M, Poolamets O, Peters M, Salumets A. Follicle-stimulating hormone receptor gene haplotypes and male infertility in estonian population and meta-analysis. Syst Biol Reprod Med. 2010;56(1):84-90 
35. Safarinejad MR, Shafiei N, Safarinejad S. Evaluating the role of the FSH receptor gene Thr307-ala and Asn680-ser polymorphisms in male infertility and their association with semen quality and reproductive hormones. BJU Int. 2011;108(2b):E117-25.

36. Huhtaniemi I: A short evolutionary history of FSH-stimulated spermatogenesis. Hormones. 2015;14(4):468-78.

Submit your next manuscript to BioMed Central and we will help you at every step:

- We accept pre-submission inquiries

- Our selector tool helps you to find the most relevant journal

- We provide round the clock customer support

- Convenient online submission

- Thorough peer review

- Inclusion in PubMed and all major indexing services

- Maximum visibility for your research

Submit your manuscript at www.biomedcentral.com/submit 